\title{
A Review on Recent Advances in Enhancing the Productivity of Guava (Psidium guajava L.) through Hi-Tech Practices
}

\author{
V.P. Santhi ${ }^{1 *}$, S. Parthiban ${ }^{2}$, K.Vijayalakshmi ${ }^{3}$, J. Auxcilia ${ }^{2}$ and P. Masilamani ${ }^{4}$ \\ ${ }^{1}$ Horticulture, Department of Fruit Science, ${ }^{2}$ Department of Fruit Science, Horticultural \\ College and Research Institute for Women, Tamil Nadu Agricultural University, \\ Trichy- 620 027, India \\ ${ }^{3}$ Department of Fruit Science, Central University of Tamil Nadu, Thiruvarur -610 005, India \\ ${ }^{4}$ Anbil Dharmalingam Agricultural College and Research Institute, Tamil Nadu Agricultural \\ University, Trichy -620 027, Tamil Nadu, India \\ *Corresponding author
}

\section{A B S T R A C T}

\begin{tabular}{l} 
Ke y w o r d s \\
Hi-tech practices, \\
Meadow orchard, \\
Canopy \\
management, \\
Fertigation, Growth \\
regulators, Micro \\
nutrients, \\
Rootstock, \\
Productivity \\
\hline Article Info \\
\hline $\begin{array}{l}\text { Accepted: } \\
\text { 18 July } 2020 \\
\text { Available Online: } \\
\text { 10 August } 2020\end{array}$ \\
\hline
\end{tabular}

Globally, India is bestowed with diverse agro-climate conditions which favour the production of a variety of fruit crops from arid, semi-arid, tropical, sub-tropical and temperate region. At present India is the second largest producer of fruits in the world after China. The need of hour is sustainable secure and affordable way to feed the entire population with nutritious food. Hence it is essential to incorporate high tech practices in our day to day cultivation practices that are potential enough to increase both quantity as well as quality of the produce. Even though, India ranks second in fruits production next to China, there is scope for increasing our productivity. In this review we have discussed an important hi - tech practices in guava for the enhancement of productivity. The novel techniques in guava practices viz., mulching, meadow orcharding, high density planting, pruning, flower induction, fruiting, fertilization, fertigation, crop regulation, foliar nutrition and crop regulation practices and using salinity tolerant rootstock improves the production, productivity and quality.

\section{Introduction}

Fruit culture is highly profitable as it increases the employment opportunities, besides commercialization is possible in the rural sector. It also provides ample opportunities for sustaining large number of agro-industries to generate substantial employment opportunities (Bardhan, 2016). Horticulture production in India increased 
substantially recent years due to adoption of advanced technologies by the farmers. The higher production is progressed due to area expansion. Over the last decade, the area under horticulture grew by $2.6 \%$ per annum and annual production increased by $6 \%$ in India. During 2018-2019 production of horticulture crops with 314.67 Million MT of horticultural produce from an area of 25.87 Million Hectares surpasses the agricultural production of 285.21 Million MT from an area of 95.45 Million Hectares (Indian Hort. Database, 2018-19). The production of fruits has increased from 50.9 MT to 96.75 MT since 2004-05 to 2018-19. Fruit crops holds second rank in production by contributing $31.5 \%$ production share. Due to tremendous increase in population and increased demand it is essential to improve the production with the available resources. Maximum of vitamin E contents was observed in Allahabad Safeda (19.4 mg/ $\mathrm{g}$ tissue) followed by Lucknow 49 (17.53 $\mathrm{mg} / \mathrm{g}$ tissue) and Arka Kiran (11.34 $\mathrm{mg} / \mathrm{g}$ tissue). reveal that guava fruits have potent antioxidant activities which may be responsible for its pharmacological effects. This can be achieved by increasing the productivity through hi-tech cultural practices. In this review, the recent hi-tech practices which have positive impact on the productivity of guava is compiled and presented

Guava (Psidium guajava) is one of the most important commercial fruits in India. Guava is native to tropical America stretching from Mexico to Peru. It is the fourth most important fruit after mango, banana and citrus. India is the major producer of Guava. The area under guava is 260.07 Thousand Ha and the production 3826.40 Thousand MT (2016-17).

The export from India is 1.23 Thousand MT and the Value is 553.26 Lakh Rupees (Indian Hort. Database, 2018-19). It grows very well in tropical as well as subtropical climate. It is considered to be more remunerative crop to the farmers due to its high productivity, easier cultivation and less cultivation cost. In the recent past, it has gained momentum owing to its versatility in adaptability to a wide range of soil conditions, especially problem soils such as saline, alkaline and even in clayey soils too. It is available at reasonable price and known for its rich nutraceutical values (Kumar and Mishra, 2012) thus, named as apple of tropics and super fruit (Maji et al., 2015). Amongst various tropical fruit crops in India, guava, if left on its own, give the variable quantities and qualities from the various flowering flushes throughout the year. In general, guava flowers twice in a year i.e. in March-April (Ambebahar) and June-July (Mrig bahar), of which fruits ripen in rainy and winter season, respectively. However, in central and Southern part of India, there is a third crop with flowers appearing in October (Hastha bahar), of which fruits ripen in the month of March was also realised. This pattern of flowering and fruiting is not desirable for commercial exploitation. Moreover, the fruits of Ambe bahar which are harvested during the months of JulySeptember and insipid, watery, and poor in quality and heavily infested with fruit fly resulting in significant loss to most of the guava growers (Mishra and Tiwari, 2000). The winter season fruits are superior in quality, free from pests which fetch high monetary returns (Singh et al., 2000).

Many works have been carried out for improving the yield and fruit quality of guava in India through various technologies (Boora et al., 2016, Lal et al., 2017, Hojo et al., 2007, Khan et al., 2011, Mamum et al., 2012, Atawia et al., 2017). Hence, it is highly essential to implement certain important modern, innovative and hi-tech methods for improving the quality as well as quantity of guava production. 


\section{High density planting}

There is a shift in farmers' insight from production to productivity and profitability which can be achieved through high density planting. High density planting has been in practice as a prime method for improving productivity of temperate fruit crops like Apple. In the past one decade, strenuous efforts were made to adopt high density planting in tropical fruit crops also. Presently, the trials on mango and guava HDP are practiced as successful technologies. Recently trials from Central Institute of Sub tropical Horticulture (CISH), Lucknow proved that guava can be successfully grown at closer spacing under high density planting to meadow orchard system with spacing of $2 \mathrm{~m}$ x $1 \mathrm{~m}$ accommodating 5000 plants / hectare. By judicious canopy management and suitable tree training systems higher and quality production is achieved from densely planted orchards by regular topping and hedging especially during early stages. Average yield obtained in meadow orchard system of guava growing is $40-60 \mathrm{t} / \mathrm{ha}$ when compare to traditional system (Singh, 2008).

Guava layers of variety Lucknow- 49, was established well at a spacing of $(3 \times 1.5 \mathrm{~m})$ accommodating 2222 plants/ hectare under sodic- alkaline soil conditions with the ESP of above $15 \%$ at $\mathrm{HC} \& \mathrm{RI}(\mathrm{W})$, TNAU, Trichy, Tamil Nadu (Auxcilia et al., 2019).

The above studies indicated that though the yield of individual plant is less under HDP, compared to moderate density or low density, owing to the increased number of plants per hectare, the total yield realised from an hectare is doubled or tripled and thus profitable to farmers.

Apart from high density planting, moderate density levels were also found to increase the productivity of guava at certain places.
According to Brar et al., (2009) fruit yield was increased significantly with decrease in density of plants during both the crop seasons. In rainy season, the yield per tree was significantly affected by plant spacing. At widest spacing of $6 \times 5 \mathrm{~m}$, highest yield of $35.15 \mathrm{~kg} / \mathrm{plant}$ was obtained, followed by $6 \mathrm{x}$ $4 \mathrm{~m}$ spacing, which gave a yield of 25.87 $\mathrm{kg} / \mathrm{plant}$ and $6 \times 2 \mathrm{~m}$ spacing gave the least yield of only $15.07 \mathrm{~kg} /$ plant. A highest yield of $17.25 \mathrm{~kg} / \mathrm{plant}$ at $6 \times 5 \mathrm{~m}$ spacing and minimum yield of $6.83 \mathrm{~kg} / \mathrm{plant}$ at $6 \times 2 \mathrm{~m}$ spacing was recorded during winter season. Similar results were reported by Lal et al., (2000). and It was concluded that a spacing of $6 \times 4 \mathrm{~m}$ with 416 plants/ha exhibited optimum microclimatic conditions in the canopies of plants and also accommodated $20 \%$ more plants when compared to the present recommendation of plant density without affecting the fruit yield and quality (Bal and Dhaliwal, 2003).

\section{Canopy management practices}

Training and pruning practices are integral part of high density planting systems. High density planting obviously needs to be combined with training and pruning techniques. Studies indicated that pruning of guava trees can enhance the productivity under high planting density. Guava responds well to pruning, because it bears fruits on current season's growth and flowers appear in leaf axils. Pruning restores the, ance between shoot and root system, besides maintains the growth and vigour of shoots by allowing fewer growing points to grow vigorously.

\section{Flower induction}

Flower production is bound to increase due to pruning, as pointed out by several studies. Singh et al., (2001) studied the effect of pruning dates on yield of guava cultivars Allahabad Safeda and Sardar for five consecutive years. They reported that pruning 
from April to June, enhanced the flowering percentage as compared to pruning in February and March. Jadhav et al., (2002) noticed that the number of flowers per shoot on severely pruned $(60 \%)$ trees of guava were more when compared to mild pruned $(30 \%)$ trees and control.

Mohammed et al., (2006) noticed that maximum flowers per shoot during winter season were in $60 \mathrm{~cm}$ pruning treatment. Mehta et al., (2012) conducted an experiment to study the effect of pruning on guava cv. Sardar under ultra-high-density orchard system.

Pruning thrice a year produced maximum number of flowers per plant (20.13), while pruning of $80 \%$ of canopy in October produced minimum number of flowers per plant (7.72) during winter season of 2009-10. To study the effect of pruning and planting systems on growth, flowering, fruiting and yield of guava cv. Sardar an experiment was conducted by Kumar and Rattanpal (2010) (Fig. 1). The results revealed that pruning the $1 / 2^{\text {nd }}$ of vegetative growth in $6 \mathrm{~m} \times 4 \mathrm{~m}$ spacing recorded the highest yield of 544 number of fruits / tree and $55.1 \mathrm{~kg} /$ tree. The estimated yield was $54.4 \mathrm{t} / \mathrm{ha}$.

\section{Fruiting}

In another study, maximum number of flower buds (62.2) was found in the treatment combination of one leaf pair pruning along with square system of planting (Pratibha et al., 2013). At CISH, Lucknow, for meadow orchard $(2 \times 1 \mathrm{~m})$, pruning of 50 per cent of the length of the shoot to produce multiple lateral shoots resulted in higher yield (10-12 $\mathrm{kg}$ fruits/plant) and pruning is ensured thrice in a year in May - June, September- October and January- February. The height of the plants was restricted to 1.0 meter from ground level (Singh, 2008).

\section{Crop regulation}

Amongst various tropical fruit crops in India, guava, if left on its own, give the variable quantities and qualities from the various flowering flushes throughout the year. Under natural conditions, these crops produce flowers thrice in a year i.e. February - March (Ambe Bahar), June -July (Mrig Bahar) and October - November (Hasth Bahar) with the corresponding harvest during rainy, winter and spring seasons, respectively (Boora et al., 2016, Lal et al., 2017).

However, the responses differed according to cultivars, tree conditions, soil types and agroclimatic conditions (Maji et al., 2015). Regulated crops are desired to avoid glut in the market and also ensure the regular supply of fruits. The choice of bahar at a particular location is determined by prevailing production constraints like availability of irrigation water, quality of produce, market demand and extent of damage by insect-pests and diseases (Lal et al., 2017).

The principle behind crop regulation is to induce flowering and fruiting in desired season of the year that contribute to increased fruit yield, quality, profitability and sustainability of the environment by reducing the use of the frequency of the pesticides (Lal et al., 2017).

\section{Gaps in prevailing system}

Fruit production is seasonal activity and during the peak season price drops sharply owing to the glut in the market. At same time in multiple flushing species like citrus, guava and pomegranate, the desired yield and quality is not obtained during the peak demand period in the market. This condition is not economically sustainable. Therefore, to obtain higher fruit yield during a particular period, these fruit crops are given a resting 
period with artificial means so that the natural flowering tendency of the trees is altered (Poerwanto et al., 2008).

To increase fruit yield, quality and profit, the flowering and fruiting of guava can be regulated to produce flower on desired season of the year. In Northern Indian Plains, adoption of various practices such as withholding irrigation after harvesting during the months of April- May is followed. Following the shedding of flowers, the tree goes to rest and irrigated in June which produces profuse flowering after 30 -35 days. By the way, the crop is regulated (Boora et al., 2016). Various methods adopted to regulate flowering in guava are as follows

\section{Withholding of irrigation water}

Withholding watering of trees from February to middle of May results in the shedding of flowers and trees go to a rest period during which accumulation of food materials takes place in branches (Sachin et al., 2015). But not sandy in heavy soils (Tiwari and Lal, 2000).

\section{Root exposure and root pruning}

Carefully, $7-10 \mathrm{~cm}$ upper soil around the tree trunk in a radius of $40-60 \mathrm{~cm}$ are removed so that roots are exposed to the sun which results in reduced moisture supply to the top, therefore, the leaves begin to shed the leaves and tree goes to a rest period. After above 3-4 weeks, the exposed roots again covered with soil and manure mixture followed by watering (Lal et al., 2017) to get a good crop (Sachin et al., 2015, Suresh et al., 2016).

\section{Shoot pruning}

Guava flowers are always borne on newly emerging vegetative shoots; irrespective of the time of years, shoot pruning have been reported to be successful. Shoot pruning is helpful in reducing the tree size and improving the fruit quality (Singh and Bal, 2006, Lal et al., 2000, Dhaliwal and Singh, 2004, Kumar and Mishra, 2010, Tiwari and Lal, 2007, Sharma et al., 2013, Prakash et al., 2012, Thakre et al., 2013, Pratibha and Lal, 2013, Thakre et al., 2016, Joshi et al., 2016, Salah, 2005). The time and intensity of pruning affected tree sprout and yield guava cv. Paluma (Sarrano et al., 2008a, Sarrano et al., 2008b), in Nepal (Adhikari and Kandel, 2015), in Cairo, Egypt (Sahar and Hameed, 2014).

\section{Deblossoming}

Deblossoming of rainy season crop subsequently increased the winter season crop (Singh et al., 2016, Lal et al., 2017). Manual deblossoming on a commercial scale is economically not viable (Singh et al., 2002). In contrast to this Das et al., (2007) found it economically profitable when $50 \%$ of rainy season crop is removed manually. Deblossoming with 100 ppm NAA (Das et al., 2007) and 200ppm NAA (More et al., 2016) were effective for guava cv. L-49 in rainfed plateau conditions in Eastern India. Flower thinning by Naphthalene Acetamide (NAD) (Maji et al., 2015), 2,4-D (Das et al., 2007), Potassium Iodide (Sachin et al., 2015) and ethephon (Singh et al., 2000). Urea spray was also found efficient for deblossoming (Singh et al., 2002).

Flower thinning during summer tends to improve fruit quality and increased the yield of winter season crop. Meanwhile, shoot bending is a highly potential method to have better quality off-season crop (Sarkar et al., 2005).

\section{Branch bending / Shoot Bending \& Fruit Thinning}

Breaking the apical dominance and activating the latent buds present on the branch (Samant 
et al., 2016) produce better quality fruits in the offseason (Sarkar et al., 2005, Mamun et al., 2012) and maintaining increased $\mathrm{C}: \mathrm{N}$ ratio and induce more flowering and fruit set (Mamun et al., 2012).

Mamum et al., (2012) studied the combined effect of variety and different management practices on fruit yield ( $\mathrm{kg} / \mathrm{plant})$ and found that was significant both in on-season and offseason (Table 1). The highest fruit yield of $23.15 \mathrm{~kg} /$ plant was obtained in the variety Chiang Mai (round) in the treatment combination of $50 \%$ fruit thinning with bending during on-season. In variety Swarupkathi the same combination treatment recorded a yield of $16.06 \mathrm{~kg} /$ plant. Treatment details were given in Table 1 .

Tahir and Hamid (2002) reported that flower and fruit drop was less due to fruit thinning which also supports the present experimental results (Fig. 2).

\section{Fertilization}

The amount of fertilizers to be applied in high density /meadow orchard of guava depends on the age of tree, condition of plant and type of soil. For proper growth and higher yield, following fertilizer doses should be applied (Table 2 and 3 ).

\section{Fertigation}

Fertilizers should be applied in a form that it becomes available in synchrony with crop demand for maximum utilization of nutrients from fertilizers. To meet the crop nutrient demand fertigation provides adequate supplies of water and nutrients with precise timing and uniform distribution. Fertigation also ensures substantial saving in usage of fertilizers and reduces leaching losses (Kumar et al., 2007) than the conventional practice, optimum split applications of fertilizer will improve quality and quantity of crop yield which is similar to frequent water application. Sharma et al., (2011) observed higher yield is obtained in guava through fertigation than basin irrigation. Jeyabal et al., (2000) observed that in a 3 year old plantation of guava, fertigation at $75 \%$ recommended NK level with urea and multi-K gave $12.3 \%$ higher yield than soil application at $100 \% \mathrm{NK}$ level indicating a saving of $25 \% \mathrm{NK}$ in addition to improvement in productivity. Ramni was et al., (2012) conducted an experiment on the effect of irrigation and fertigation scheduling on growth and yield of guava under meadow orchard system $(2 \times 1 \mathrm{~m})$ in guava var. Shweta. The results indicated that the maximum fruit diameter $(6.69 \mathrm{~cm})$ (polar) and $5.97 \mathrm{~cm}$ (equatorial) and fruit weight $(182.17 \mathrm{~g})$ were recorded with application of 100 per cent irrigation of water/cumulative pan evaporation $+100 \%$ water soluble fertilizers. However, maximum benefit:cost ratio of 2.91 was obtained with $75 \%$ of irrigation of cumulative pan evaporation along with $75 \%$ of water soluble fertilizers, and hence, this can be considered as the best treatment. Sharma et al., (2013) reported that the highest fruit yield of guava (18.7 $\mathrm{t} / \mathrm{ha}$ ) was obtained with drip irrigation at $100 \%$ ETc, while the lowest yield ( $11.0 \mathrm{t} / \mathrm{ha})$ was obtained with drip irrigation at $60 \%$ ETc. The interaction between irrigation schedules and $\mathrm{N}$ fertigation levels revealed that maximum fruit yield of $21.6 \mathrm{t} / \mathrm{ha}$ and water productivity of $17.8 \mathrm{~kg} / \mathrm{ha}-\mathrm{mm}$ was demonstrated under drip irrigation at $100 \%$ ETc with $120 \%$ of recommended dose of $\mathrm{N}$.

Fertigation scheduling for HDP in guava cv. Lucknow, the crop yielded on an average of $4.60 \mathrm{~kg}$ fruits/plant and the highest estimated fruit yield of 10.22 tonnes/ha at a fertigation dose of $50 \%$ of RDF (300:150:150g/ plant/year) as against 6.73 tonnes/ha in control with soil application of $100 \%$ RDF (Auxcilia et al., 2019). 
Table.1 Effect of fruit thinning of on- season and off- season on guava yield

\begin{tabular}{|l|c|c|c|c|c|c|}
\hline \multirow{2}{*}{ Management practices } & \multicolumn{2}{|c|}{$\begin{array}{c}\text { Percent fruit drop } \\
(\mathbf{\%})\end{array}$} & \multicolumn{2}{c|}{$\begin{array}{c}\text { Percent fruit } \\
\text { retention (\%) }\end{array}$} & \multicolumn{2}{c|}{ Yield (kg/plant) } \\
\cline { 2 - 7 } & $\begin{array}{c}\text { On } \\
\text { Season }\end{array}$ & $\begin{array}{c}\text { Off } \\
\text { Season }\end{array}$ & $\begin{array}{c}\text { On } \\
\text { season }\end{array}$ & $\begin{array}{c}\text { Off } \\
\text { Season }\end{array}$ & $\begin{array}{c}\text { On } \\
\text { season }\end{array}$ & $\begin{array}{c}\text { Off } \\
\text { Season }\end{array}$ \\
\hline Control & 31.87 & 25.26 & 68.13 & 74.83 & 13.67 & 8.43 \\
\hline Shoot bending & 29.33 & 24.42 & 70.75 & 76 & 16.66 & 13.5 \\
\hline $\mathbf{2 5 \%}$ fruit thinning & 16.61 & 14.5 & 83.39 & 85.5 & 16.9 & 10.16 \\
\hline $\mathbf{5 0 \%}$ fruit thinning & 10.72 & 9.53 & 89.28 & 90.47 & 20.46 & 12.43 \\
\hline $\mathbf{7 5 \%}$ fruit thinning & 11.55 & 9.96 & 88.45 & 90.04 & 10.06 & 8.09 \\
\hline $\mathbf{1 0 0 \%}$ fruit thinning & 0 & 9.63 & 0 & 90.37 & 0 & 7.19 \\
\hline
\end{tabular}

Source: Mamun et al., 2012

Table.2 Fertiliser doses for meadow orchard of guava

\begin{tabular}{|c|c|c|c|c|}
\hline \multicolumn{5}{|c|}{$\begin{array}{l}\text { For spacing of } 3.0 \times 1.5 \mathrm{~m}(2222 \text { plants/ha }) ; 3.0 \times 3.0 \mathrm{~m}(1111 \text { plants/ha }) \text { and } 6.0 \times 3.0 \\
\text { (555 plants/ha) }\end{array}$} \\
\hline \multirow[t]{2}{*}{ Year } & \multicolumn{2}{|c|}{ Urea (g/ plant) } & $\mathrm{SSP}$ (g/ plant) & MOP (g/ plant) \\
\hline & June & September & September & June \\
\hline $1^{\text {st }}$ & 182 & 78 & 375 & 100 \\
\hline $2^{\text {nd }}$ & 364 & 156 & 750 & 200 \\
\hline $3^{\text {rd }}$ & 546 & 234 & 1125 & 300 \\
\hline $4^{\text {th }}$ & 728 & 312 & 1500 & 400 \\
\hline $5^{\text {th }} \&$ above & 910 & 390 & 1875 & 500 \\
\hline
\end{tabular}

Table.3 Fertiliser doses for high density orchard of guava

\begin{tabular}{|c|c|c|c|c|}
\hline \multicolumn{5}{|c|}{ For spacing of $2.0 \times 1.0 \mathrm{~m}$ (5000 plants/ha) } \\
\hline \multirow[t]{2}{*}{ Year } & \multicolumn{2}{|c|}{ Urea (g/ plant) } & \multirow{2}{*}{$\begin{array}{l}\text { SSP (g/ plant) } \\
\text { September }\end{array}$} & \multirow{2}{*}{$\begin{array}{c}\text { MOP (g/ plant) } \\
\text { June }\end{array}$} \\
\hline & June & September & & \\
\hline $1^{\text {st }}$ & 90 & 40 & 185 & 50 \\
\hline $2^{\text {nd }}$ & 180 & 110 & 370 & 100 \\
\hline $3^{\text {rd }}$ & 270 & 115 & 555 & 150 \\
\hline $4^{\text {th }}$ & 360 & 150 & 740 & 200 \\
\hline $5^{\text {th }} \&$ above & 450 & 190 & 900 & 250 \\
\hline
\end{tabular}


Fig.1 Fruit yield of Sardar under different pruning intensities

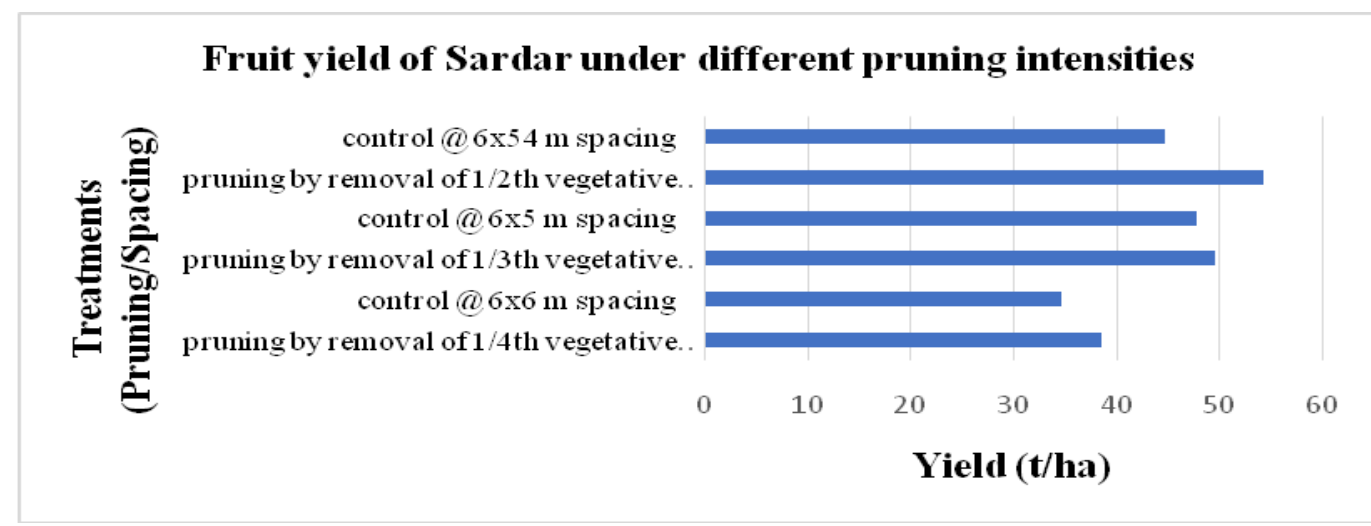

Source: Kumar and Rattanpal, (2010).

Fig.2 Effect of different management on per cent fruit drop, per cent fruit retention and yield in guava

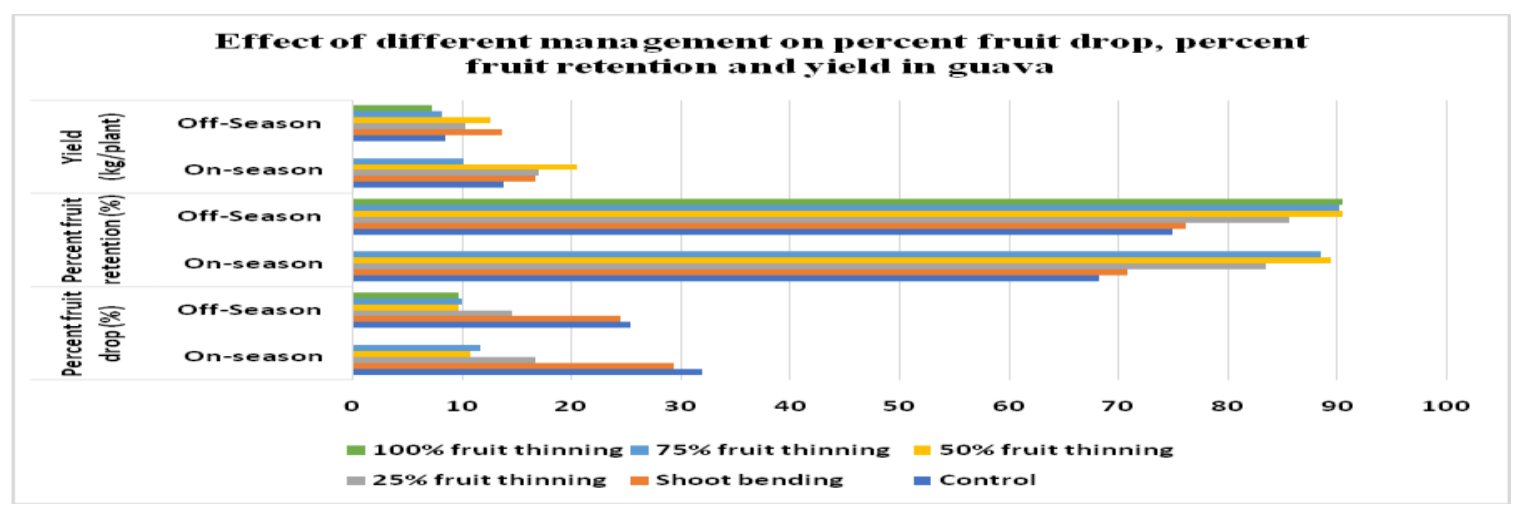

Source: Tahir and Hamid (2002)

Fig.3 Effect of foliar nutrition in growth and yield of guava

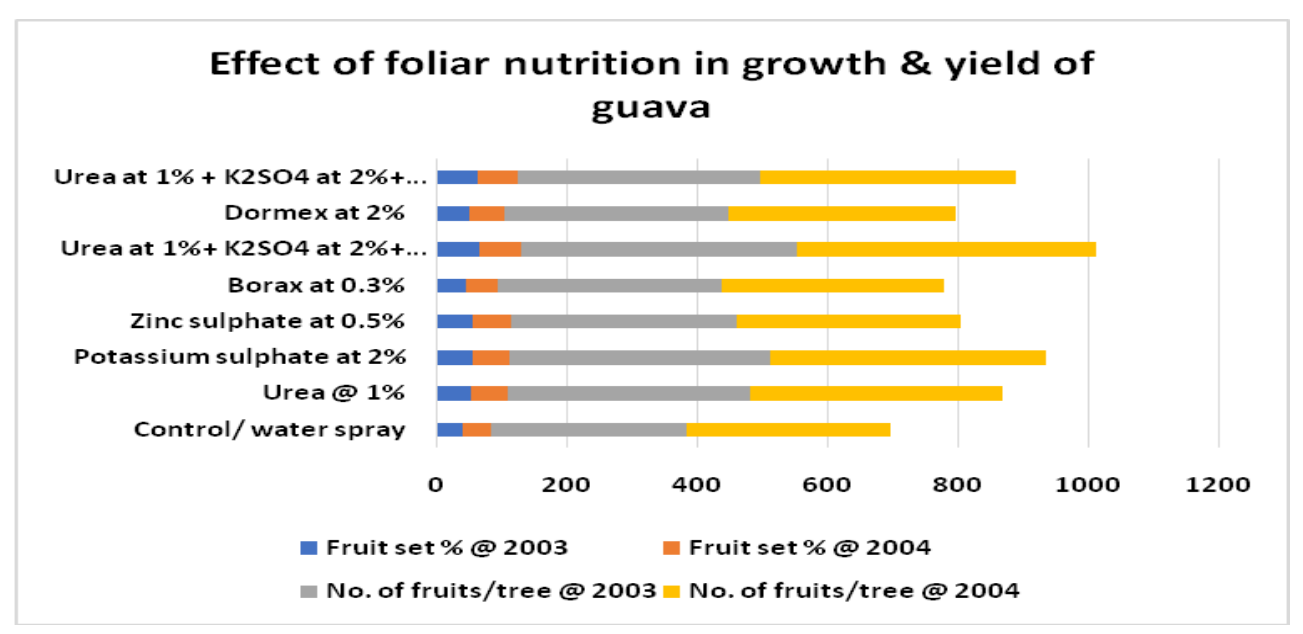




\section{Mulching}

A study was conducted to evaluate the effect of organic and inorganic mulching materials on growth, fruiting and fruit quality of guava, grown on new alluvial zone of West Bengal. Different soil covers were used in the experiment instead of using polythene mulch as control. The soil covers used were cover crops like cowpea, Sugarcane trash $(\mathrm{O} \mathrm{cm}$ thickness), Saw dust (5 cm thickness), Dry guava leaves (10 cm thickness), Paddy straw $(10 \mathrm{~cm}$ thickness), black polythene (250 gauge) and white polythene (250 gauge). Maximum number of fruits (347.95) and the highest yield $(47.05 \mathrm{~kg})$ per plant was obtained when black polythene was used as a mulch (Das et al., 2010). Different mulching treatments also showed increase in weight of individual fruit, number of fruits per plant, yield of fruit per plant as well as per hectare.

\section{Foliar nutrition}

Khamis et al., (2007) studied that spray the guava trees with Dormex at $2 \%$ in January then sprays twice with combination from (urea at $1 \%+\mathrm{K}_{2} \mathrm{SO}_{4}$ at $2 \%+\mathrm{ZnSO}_{4}$ at $0.5 \%$ + Borax at $0.3 \%$ ) at full bloom and after fruit set (one month later) to improve vegetative growth; nutritional status; yield and fruit quality of guava (Fig. 3).

\section{Root stock}

Collection and evaluation of guava germplasm for physiological and biochemical basis for sodicity tolerance studies were carried out at Horticultural College and Research Institute for Women, Trichy during 2014 to 2019. 34 different accessions of guava were collected and evaluated for yield and physiological and biochemical parameters under saline- sodic condition. The maximum physiological activity and leaf $\mathrm{K} / \mathrm{Na}$ ratio was recorded in Mirzapur Seedling (20.155) followed by Karela (18.928) and minimum recorded in Seedless (1.604). The maximum leaf $\mathrm{K} / \mathrm{Ca}+\mathrm{Mg}$ ratio was recorded in Cheeni guava (0.156) followed by Mirzapur Seedling (0.134) and minimum recorded in Lucknow 46 (0.008). Mirzapur Seedling, Cheeni guava and Karela could be used as rootstock under saline condition (Santhi et al., 2019) which increases the area and productivity of guava in India.

It is concluded that the above-mentioned novel techniques for guava is scientifically proven that are highly potential enough to improve the crop productivity. The ultimate aim is to increase the productivity per unit area with the effective utilization of optimum inputs. All these studies showed that productivity can be increased by increasing the population per unit area. It is certain that the increased population will not alone perform well unless their stature maintained according to the space allotted to each of them. Hence, it is important to adopt canopy management and crop regulation practices viz., pruning, withholding of irrigation water, root exposure and root pruning, shoot pruning, shoot bending, deblossoming practices and using saline tolerant rootstock etc. Even though number of plants with welldeveloped frame work is maintained, the plants may starve for nutrients due to competition. This can be overcome by following the nutrient recommendation standardized for particular planting density. Fertigation and micronutrient application are the major practices in guava to obtain higher yields. The method of application of all essential inputs viz., growth regulators, and micro nutrients for plant growth also had influence on crop growth and productivity. For instance, using drip system for irrigation and fertigation ensure effective uptake of water and nutrients by the plants. Hence it is clear that the technologies capable of improving plant growth via different cultural 
practices have to be utilized in an integrated manner for getting remarkable results. So, it is our duty to popularize and handover these techniques to farmers so that our ultimate goal can be achieved practically.

\section{References}

Adhikari, S and Kandel, T.K. 2015. Effect of time and level of pruning on vegetative growth, flowering, yield and quality of guava. Int. J. Fruit Sci., 15(3):290-301.

Atawia, A.A.R., El-Gendy, F.M.A., Bakry, Kh.A.I., Abd El-Ghany, N.A. and Singer, M.A.A. 2017. Physiological studies on flowering and fruiting of guava trees. Middle East J. Agric., 6(1):143-151.

Bal, J.S., Dhaliwal, G.S., 2003. High density planting studies in guava. Haryana $J$. Hort. Sci. 32, 19-22.

Bardhan, K. 2016. Crop Regulation: Concepts and its Commercial Uses. In: Commercial Horticulture, Patel N.L., Chawla, S.L. and Ablawat, T.R. (Eds.), New India Publishing Agency, New Delhi, pp. 257-275.

Boora, R.S., Dhaliwal, H.S. and Arora, N.K. 2016. Crop regulation in guava $-\mathrm{A}$ review. Agric. Rev., 37(1):1-9.

Brar, J.S., Bali J.S., Singh, S.P., 2009. Relationship between canopy microclimate and flowering \&fruiting behaviour of guava plants at varied densities. Journal of Agro meteorology. 11 (Special Issue), 121128.

Das, B., Nath, V, Jana, B.R., Kumar, S. and Dey, P. 2007. Evaluation of crop regulation in guava grown under rainfed plateau conditions of eastern India. Indian J. Hort., 64(3): 294-299.

Das, B.C., Maji, S., Mulieh, R., 2010. Response of soil covers on guava cv. L-49. Journal of Crop and Weed. 6
(2), 10-14.

Dhaliwal, G.S. and Singh, R. 2004. Effect of different pruning levels on vegetative growth, flowering and fruiting in Sardar guava. Haryana J. Hort. Sci., 33(3-4): 175-177.

Gurusamy, K., V.P. Santhi, K. Indhumathi and S. Parthiban. Evaluation of antioxidant constituents of guava varieties grown under salt affected soil. national conference climate smart agriculture for livelihood security: challenges and opportunities 13-14, September 2019 held at Anbil Dharmalingam Agricultural College and Research Institute. Souvenier. : 67

Hojo, R.H., N.N.J. Chalfun, E.T.D. Hojo, R.D. Veiga, C.M. Paglis and L.C. deO-Lima. (2007). Production and quality of guava fruits 'Pedro Sato' submitted to different pruning times. Pesq. Agropec, Brasil., 42:357-362.

Auxcilia, J., S. Parthiban, V.P. Santhi, A. Nithyadevi, P.Janaki and I. Indurani. 2019. Studies on fertigation scheduling for guava $\mathrm{Cv}$. Lucknow 49 in sodic soil conditions under High Density Planting Systems. Paper presented on National conference Climate smart agriculture for livelihood security: challenges and opportunities 13-14, September 2019 held at Anbil Dharmalingam Agricultural College and Research Institute. Souvenier. Pp. 57.

Jadhav, B.J., Mahurkar, V.K., Kale, V.S. 2002. Effect of time and severity of pruning on growth and yield of guava (Psidium guajava L.) cv. Sardar. Orissa J. Hort.30 (2), 83- 86.

Khamis, M.A., Bakry, Khaled and Moty, S.A. (2007). Improving growth and productivity of guava trees. Minia $J$. Of Agric. Res. And Devel. 27(1): 5170.http://dx.doi.org/10.1590/141370542016403033315 
Khan, A.S., Khan, M.R.G. Malik, A.U., Saleem, B.A., Rajwana, I.A and Ahmad, I. 2011. Influence of defoliation and deblossoming on the vegetative and reproductive growth of guava (Psidium guajava L.) Cv. Gola. Pak. J. Bot., 43(6):2891-2896.

Kumar, A., Singh, R.K., Sinha, A.K., Singh, H.K., Mishra, A.P., (2007). Effect of fertigation on banana through drip irrigation in North Bihar. J. Res. Birsa Agric. Univ. 19, 81-86.

Kumar, R. and Mishra, D.S. 2010. Amrud ki labhkari kheti. Kisan Bharti, 41(10):56.

Kumar, R. and Mishra, D.S. 2012. Guava: A health capsule. Indian Farmar's Digest, 45(8):30-32.

Kumar, Y., Rattanpal, H.S., 2010. Effect of pruning in guava planted at different spacing under Punjab conditions. Indian J. Hort. 67(Special Issue), 115 119.

Lal, N., Sahu, N., Marboh, E.S., Gupta, A.K. and Patel, R.K. (2017). A review on crop regulation in fruit crops. Int. $J$. Curr. Microbio. App. Sci., 6(7):40324043.

Lal, S. Tiwari, J.P. and Misra, K.K. 2000. Effect of plant spacing and shoot pruning intensity on fruit yield and quality of guava. Prog. Hort., 32:2025.

Lal, S., Tiwari, J.P., Misra, K.K., 2000. Effect of plant spacing and pruning intensity on fruit yield and quality of guava. Prog. Hort. 32, 20-25.

Maji, S., Das, B.C. and Sarkar, S.K. 2015. Efficiency of some chemicals on crop regulation of Sardar guava. Sci. Hortic., 188:66-70.

Mamum, A.A., Rahman, H., Rahim, M.A., 2012. Effect of Shoot Bending and Fruit Thinning on Productivity of Guava. J. Environ. Sci. \& Natural Resources.5 (2), 167 -172.
Mehta, S., Singh, S.K., Das, B., Jana, B.R., Mali, S., 2012. Effect of pruning on guava cv. Sardar under ultra high density orcharding system. Indian Journal. 25(2), 192-195.

Mishra, D.S and Tiwari, J.P. 2000. Guava: a potential fruit of subtropical and India. Swarna Sedyam, 3(9):47-49.

Mohammed, S., Sharma, J.R., Kumar, R., Gupta, R.B., Singh, S., 2006. Effect of pruning on growth and cropping pattern in guava cv. Lucknow-49. Haryana J. Hort. Sci. 35(3\&4), 211212.

More, D.B., Raut, U.A. and Bongane, Y.S. 2016. Effect of Different Growth Regulator on Vegetative Growth, Flowering and Yield of Winter Season Guava cv. Sardar. Adv. Life. Sci., 5(12):5064-5066.

Poerwanto, R. Efendi, D., Widodo, W.D. Susanto, S. and Purwoko, B.S. (2008). Off season production of tropical fruits, Acta Hort., 772:127-133.

Prakash, S. Kumar, V., Saroj, P.L. and Sirohi, S.C. 2012. Response of yield and quality of winter guava to severity of summer pruning. Indian J. Hort., 69(2): 173-176.

Pratibha, Shant L., Goswami, A.K., 2013. Effect of pruning and planting systems on growth, flowering, fruiting and yield of guava cv. Sardar. Indian J. Hort. 70 (4), 496-500.

Ramnivas, R., Kaushik, A., Sarolia, K, Sunil Pareek and Singh, V. 2012. Effect of irrigation and fertigation scheduling on growth and yield of guava (Psidium guajava L.) under meadow orcharding. African Journal of Agricultural Research: 7(47), pp.6350-6356.

S.Parthiban, V.P.Santhi and J. Auxcilia. 2019. Enhancing the productivity of fruit crops through hi tech practices. Invited paper on National conference 
Climate smart agriculture for livelihood security: challenges and opportunities 13-14, September 2019 held at Anbil Dharmalingam Agricultural College and Research Institute. Souvenier. pp 143 -155.

Sachin, A.J., Ramteke, V. and Bharath, K.R. 2015. Flower Regulation in Guava and Pomegranate. Prop. Kheti, 3(4):53-54.

Sahar, A.F and Hameed, A.A.A. 2014. Effect of pruning on yield and fruit quality of guava trees. J. Agric. Vet.Sci., 7(12):41-44.

Salah, A. El-D.M. 2005. Effect of pruning on growth, flowering and fruiting of some guava cultivars. M.Sc., Thesis, Fac. Agric, Cairo Univ.

Santhi, V.P., A. Ramesh Kumar , K. Gurusamy, J. Auxcilia and S.Parthiban. 2020. Collection and Evaluation of Guava Germplasm for Physiological and Biochemical Basis for Sodicity Tolerance. Paper presented on National conference Climate smart agriculture for livelihood security: challenges and opportunities 13-14, September 2019 held at Anbil Dharmalingam Agricultural College and Research Institute. Souvenier. pp :55.

Sarkar, A., Ghosh, B., Kundu, S., Sukul, P., 2005. Effect of shoot pruning and bending on yield and fruit quality in guava cv. L-49. Environ. Ecol.23 (3), 621-623.

Sarrano, L.A.L, Marinho, C.S., Gabetto, E., Silva, M. and Tardin, F.D. 2008a. Phenological and yield characteristics of "Paluma" guava tree pruned in different times and intensities, in north of Rio De Jeneiro State, Brazil. Revista Ceres., 5(5): 416-424.

Sarrano, L.A.L, Martins, M.V.V., Lima, I.De M., Marinho, C.S. and Tardin, F.D. 2008b. Effect of pruning time and intensity on Paluma' guava trees, in
Pinheiros, ES, Brazil. Revista Brasileira de Fruticultura, 30(4): 9941000.

Sharma, A., Wali, V.K. Sharma, R.M., Jamwal, M. and Sharma, B. 2013. Effectiveness of Various Crop Regulation Treatments in Guava (Psidium guajava) cv. L-49. Madras Agric. J., 100 (1-3): 747-750.

Sharma, S., Patra, S.K., Ray, R., 2011. Effect of drip fertigation on growth and yield of guava cv. Khaja. Environ. Eco. 29, 34-38.

Sharma.S, Sanmay KR. Patra, Gokul B.Roy and Soumen Bera. 2013b. Influence of drip irrigation and nitrogen fertigation on yield and water productivity of guava. The Bioscan, 8(3): 783-786.

Singh, G., 2008 \& 2013. High density and meadow orcharding in guava. A Technical Bulletin Published by Central Institute for Subtropical Horticulture, Lucknow. 1-20.

Singh, G., Singh, A.K. and Verma, A. 2000. Economic evaluation of crop regulation treatment in guava (Psidium guajava). Indian J. Agric. Sci., 70(4):226-230.

Singh, G., Singh, A.K., Rajan, S. and Bhriguvanshi, S.R. 2002. Strategy of crop regulation in guava (Psidium guajava L.) through foliar urea sprays and its effect on different $\mathrm{N}$-forms in leaves. J. Appl. Hort., 4(2):93-98.

Singh, G., Singh, A.K., Rajan, S., 2001. Influence of pruning date on fruit yield of guava (Psidium guajava L.) under subtropics. J. Appl. Hort. 3(1), 37-40.

Singh, H.J. and Bal, J.S. $2006 . \quad$ Effect of pruning and growth regulators on physio-chemical characters of guava during rainy season planted at different spacing. Intr. J. Agric. Sci., 2(2):533-537.

Summat D., Kishore, K. and Singh, H.S. 
2016. Branch bending for crop regulations in guava under hot and humid climate of eastern India. $J$. Indian Soc. Coastal Agric. Res., 34(1):92-96.

Suresh, M., Kumar, S. and Swaminathan, V. 2016. Crop Regulation in Guava (Psidium guajava L.) A Review. Agric. Sci., 5(12): 458-459.

Tahir, F.M., Hamid, K., 2002. Studies of physico-chemical changes due to fruit thinning in Guava (Psidium guajava L.). J. Biol. Sci. 2, 744-745.

Thakre, M.B., Lal, S., Goswami, A.K., Prakash, P. 2013. Effect of various methods of crop regulation in guava under double-hedge row system of planting. Indian J. Hort., 70(2):211216.

Thakre, M.B., Lal, S., Uniyal, S., Goswami, A.K., Prakash, P. 2016. Pruning for crop regulation in high density guava (Psidium guajava L.) plantation. Spanish J. Agric. Res., 14(2)1-8. http://dx.xoi.org/10.5424/sjar/2016142 $-7846$.

Tiwari, J.P. and Lal, S. 2000. Amrud ki kheti tatha bagh prabandh. Dir. Publ., GBPUAT, Pantnagar, pp. 47.

Tiwari, J.P. and Lal, S. 2007. Effect of NAA, flower bud thinning and pruning on crop regulation in guava (Psidium guajava L.) cv. Sardar. Acta. Hort., 735:311-314.

\section{How to cite this article:}

Santhi, V.P., S. Parthiban, K.Vijayalakshmi, Auxcilia and Masilamani, P. 2020. A Review on Recent Advances in Enhancing the Productivity of Guava (Psidium guajava L.) through HiTech Practices. Int.J.Curr.Microbiol.App.Sci. 9(08): 1922-1934. doi: https://doi.org/10.20546/ijcmas.2020.908.220 